\title{
Kleptomania in a 15-year-old boy with ADHD - a case report
}

\author{
Kleptomania u 15-letniego chłopca z ADHD - opis przypadku
}

\section{Olga Padała ${ }^{1}$ ABDE https://orcid.org/0000-0003-1469-0877, Sebastian Masternak ${ }^{2}$ AEF, Agata Makarewicz ${ }^{1}$ Aв, Agnieszka Biała-Kędra ${ }^{1}$ ABDE, Kaja Karakuła ${ }^{3}$ EF https://orcid.org/0000-0003-1493-8502}

${ }^{1}$ I Department of Psychiatry, Psychotherapy and Early Intervention, Medical University of Lublin, Poland

${ }^{2}$ Independent Public Health Care Facility of the Ministry of Interior and Administration in Lublin, Poland

${ }^{3}$ Student Scientific Club at the I Department of Psychiatry, Psychotherapy and Early Intervention, Medical University in Lublin, Poland

\begin{abstract}
Aim: The aim of the study was 1) to report the case of a 15-year-old boy who developed kleptomania symptoms during methylphenidate treatment and 2) to review the available therapeutic options for kleptomania based on a literature search of Medline and Google Scholar databases (2000-2018).

Case report: For the past seven years a 15-year-old boy had participated in counselling at a psychological counselling centre because of school problems and upbringing difficulties, and had a five-year history of psychiatric treatment for ADHD. He was admitted to the Department of Psychiatry because of recurrent stealing episodes that occurred during methylphenidate treatment. During the hospitalization, the patient did not observe the therapeutic contract - he stole items from other patients. Pharmacotheraputic and psychotherapeutic treatment resulted in a partial improvement in impulsive behaviour. At discharge, he spoke critically of his previous conduct and expressed readiness to continue treatment in an outpatient setting.

Conclusions:

1. Kleptomania has a very negative impact on a patient's overall well-being.

2. In the reported case, kleptomania developed during methylphenidate treatment.

3. Kleptomania should always be taken into account as a possible cause of stealing during a psychiatric examination, to avoid stigmatization of patients as criminals.

4. Pharmacotherapy and cognitive-behavioural psychotherapy focused on the development of strategies, which can help the patient to control the urge to steal, are important components of kleptomania treatment.
\end{abstract}

Keywords: kleptomania, impulse control disorders, psychotherapy, methylphenidate

\section{Streszczenie}

Cel pracy: Celem pracy było 1) przedstawienie opisu 15-letniego chłopca, u którego w trakcie leczenia metylofenidatem doszło do rozwoju kleptomanii, 2) przegląd dostępnych opcji terapeutycznych kleptomanii na podstawie przeglądu literatury z bazy Medline i Google Scholar (lata 2000-2018).

Opis przypadku: Chłopiec lat 15, od 7 lat pod opieką poradni psychologicznej z powodu problemów szkolnych i trudności wychowawczych oraz od 5 lat pod opieką psychiatry z powodu zdiagnozowanego i leczonego ADHD. Powodem przyjęcia do Kliniki Psychiatrii były pow tarzające się epizody kradzieży, które pojawiły się w trakcie leczenia metylofenidatem. Pacjent przez większość czasu podczas hospitalizacji nie przestrzegał kontraktu terapeutycznego, dopuszczając się kradzieży. Pod wpływem zastosowanego leczenia farmako- i psychoterapeutycznego uzyskano częściową poprawę z zakresie zachować impulsywnych. W dniu wypisu wyrażał krytycyzm wobec swoich czynów oraz chęć kontynuowania leczenia w warunkach ambulatoryjnych. Wnioski:

1. Kleptomania jest zaburzeniem wpływającym bardzo niekorzystnie na całokształt funkcjonowania pacjenta.

2. W opisanym przypadku kleptomania rozwinęła się $w$ trakcie przyjmowania metylofenidatu.

3. Zawsze należy brać pod uwagę kleptomanię w trakcie badania psychiatrycznego osoby dopuszczającej się 
kradzieży, aby nie stygmatyzować osoby chorej klasyfikując ją jako przestępcę.

4. Istotnymi elementami leczenia kleptomanii jest farmakoterapia i psychoterapia kognitywno-behawioralna ukierunkowanej na rozwój strategii pozwalających na opanowanie impulsów popychających do kradzieży.

Słowa kluczowe: kleptomania, zaburzenia kontroli popędów, psychoterapia, Metylofenidat

\section{Introduction}

Kleptomania (compulsive stealing) is defined in ICD 10 and ICD 11 as "the recurrent failure to resist the impulse to steal items of little intrinsic value" [1, 2]. In ICD 10 , the disorder is grouped with "habit and impulse control disorders" (F63.2) along with pathological gambling, pyromania, trichotillomania, other unspecified habit and impulse disorders and unspecified habit and impulse disorders. In ICD 11, it is classified together with "impulse control disorders" such as pyromania, compulsive sexual behaviour disorder, intermittent explosive disorder and other specified and unspecified impulse control disorders. There are no epidemiological data on the prevalence of kleptomania in the general population. It is estimated that about $5 \%$ of people who have committed theft may be suffering from compulsive stealing [3]. There are studies which indicate that $7.8 \%$ of people suffering from mental disorders show symptoms of kleptomania [4]. As many as $75 \%$ of kleptomania patients are women, mostly young ones before the age of 20 [5]. Three forms of this disorder have been described: 1 - brief stealing episodes with long periods of remission, 2 - protracted periods of stealing with brief periods of remission, and 3 - continuous stealing with little variation in frequency. Diagnosis of kleptomania is based on two criteria: the occurrence of two or more acts in which the person steals without any apparent motive of gain for the individual or another person and a feeling of strong tension before the act and a sense of relief afterwards. Differential diagnosis should include depressive disorder with stealing (F31F33), organic mental disorders (F00-F09), and recurrent stealing without a mental cause when the acts have been carefully planned and there is an obvious motive of personal gain. Kleptomania cannot be diagnosed when the stealing has been committed under the influence of productive symptoms [1]. DSM-5 also emphasizes that a person suffering from kleptomania is usually able to refrain from stealing when there is a significant and immediate likelihood of consequences [6].

\section{A historical outline}

Compulsive stealing was first described in 1816 by the Swiss physician André Matthey, who wrote about thieves who had impulsively stolen things they did not need [7]. The term 'kleptomania' was first used in 1838 by two French psychiatrists, Jean-Étienne Dominique Esquirol and Charles Chrétien Henri Marc, to describe cases of kings who had experienced an unrestrained urge to steal worthless objects. These physicians believed this impulse to appropriate other people's property was associated with a mental disorder rather than a lack of moral principles. At that time, the disorder was attributed mainly to women, with uterine disease or premenstrual syndrome considered to be the potential causes of the behaviour. At the beginning of the 20th century, kleptomania was classified as an impulse control disorder. In 1952 it was included in DSM-I. In subsequent years, however, the existence of kleptomania was questioned, as reflected in the fact that it was not recognized as a disease entity in DSM-II in 1968. DSM-III again featured kleptomania as an impulse control disorder, grouping it with pyromania, trichotillomania, intermittent explosive disorder and pathological gambling [8].

\section{Case report}

A 15-year-old boy was admitted to the youth ward of the Department of Psychiatry in May 2018. He had not been hospitalized in psychiatric wards before. Since 2011, he had attended counselling at a psychological counselling centre because of school problems difficulty concentrating, attention deficit, poor academic performance and aggressive behaviour. Periodically, he had had sleep problems related to stress experienced at school, and bit his nails. Since 2017, the patient had been treated for ADHD by a child psychiatrist, who had prescribed a daily dose of $20 \mathrm{mg}$ methylphenidate. Perinatal and somatic histories were not significant. An EEG was normal; A MRI showed an ambiguous $10 \mathrm{~mm} \times 5$ $\mathrm{mm}$ loss of contrast enhancement at the junction between the right transverse and sigmoid sinuses and transverse sinus asymmetry. The patient had no family history of psychiatric disorders. The boy and his family did not report substance abuse.

\section{Reasons for hospitalization:}

The boy was admitted to hospital because of repeated episodes of stealing of small items from school and stores. The first act took place in February 2017, when the patient stole a phone from a friend. The parents noticed that the problem had exacerbated in the previous 6 months. In April 2018, the boy stole about 15 euro's worth of merchandise (toy bricks and a power bank) from a supermarket. When asked about the motives of his behaviour, he claimed that he had been driven by an uncontrollable impulse to steal. 
He usually returned the objects he stole to the owner or left them in a place where they could be easily recovered. In some exceptional cases, he kept the loot for himself. He was on police record for petty theft and shoplifting.

\section{Family situation:}

The patient lived with his parents in a family home in a medium-sized city. He had an older brother who lived and studies at a university of technology in a city about 100 kilometres away. The large age difference (8 years) between the brothers was due to the fact that the second pregnancy had not been planned. The patient's parents had been treated for infertility. After the birth of their first son, they were convinced that they could not have any more children. The news of the second pregnancy came as a surprise to them. At conception, the boy's mother was 40 years old, and the father was 43 . The history taken from the patient's parents shows that the brothers had quite different lifestyles. The parents emphasized that the older son had never caused any educational problems. They often compared their sons, pointing to the huge dissonance in the emotional and intellectual development between the brothers. The parents found it difficult to accept the way their younger son lived and the level at which he functioned. The mother was a dressmaker and the father worked in a steel mill. The patient assessed his relations with the family members as good. The boy reported quarrels at home during which vulgar language had been used. The boy's father behaved aggressively after drinking alcohol. The patient sometimes got into a fight with his brother, and was unable to say why such situations occurred. The parents had used corporal punishment, spanking the boy with a belt or a cable. The boy had no clearly defined household duties - his mother did the housework.

\section{School situation:}

The patient was a 3rd grade middle school student. He was in an integrated class. He had been having cognitive and behavioural problems at school since day one - an attention deficit, aggressive behaviour towards peers, difficulty concentrating, and dysgraphia. Most of his marks were ECTS Es ("sufficient performance") and he had never repeated a grade. The patient admitted to sometimes having come into conflict with peers and teachers. In his free time, the boy liked to walk with his dog, play football, play computer games and work with his dad in a woodworking workshop.

The patient had had a problem adapting and fitting in at middle school. None of his primary school classmates attended the new school. Also, he felt that the fact that he had been placed in an integrated class highlighted

his otherness, i.e. his poorer intellectual performance.

\section{Psychological assessment:}

The psychological assessment carried out during hospitalization showed that the subject's intellectual ability was below average: he had a full scale score II =

76. The results of the tests pointed to a nonharmonious development of the cognitive functions. A comparison of the patient's scores on the verbal scale (II verb $=72$ ) and the non-verbal scale (II nverb $=86$ ) indicates that his abilities in the latter area were superior to those in the former area. Considering the patient's scores, especially the subtest scatter (differences in subtest scores greater than 10 points), his verbal and non- verbal intelligence quotients should be interpreted with great caution. It seems that in the analysed case, a more accurate description of the patient's intellectual ability could be obtained using three-factor analysis. The three-factor model includes the following factors: Verbal Comprehension (VC), Perceptual Organisation (PO), and Memory/ Freedom from Distractibility (MFD). VC measures verbal knowledge and understanding acquired through formal and informal learning. It shows whether the subject is able to apply his/her verbal skills to new situations. PO reflects the subject's ability to interpret and process visual material under a time limit. MFD is considered to be a good measure of attention and concentration, it includes subtests that engage short-term memory and number manipulation.

An analysis of the patient's scores on the WISC-R subtests corresponding to the individual factors shows that the patient only had an average score on the PO subscales. The scores obtained on the VC and MFD subscales indicate that the boys intellectual functions measured by these factors were poorly developed. The literature emphasises that patients diagnosed with the hyperkinetic syndrome score low on PO [9]. This relationship was also found in the present case. The boy's low scores on VC subtests are reflected in his poor school marks and substantial gaps in formal and world knowledge. It can be assumed that the primary cause of the patient's learning difficulties were deficits in attention and concentration, which contributed to numerous school failures. These, in turn, led to a decrease in the motivation to learn and aversion to intellectual effort, and, as a result, aggravated the existing deficits in school knowledge. Considering the patient's present problem - kleptomania, the current assessment of his intellectual abilities does not bode well for the success of cognitive-behavioural psychotherapy. In his case, the use of strictly behavioural interventions seems more justified than the application of cognitive techniques. 


\section{Description of the patient's drawing:}

The boy made the drawing (Fig. 1) spontaneously in his free time. He reported that he had drawn the picture "out of boredom, because it was a weekend, there were no classes or any other activities."

In the central part of the picture, there is a building with the inscription "MILICJA" ('militia', a term used for the police in the communist days). On the left, the patient has drawn a policeman and a police car, which he has also labelled "MILICJA". On the right side of the picture there are three human figures, two of them are holding hands. The third person is holding a basket and collecting fruit. The drawing also features clouds, the sun, three trees and flying birds. The patient explained why he had used the word MILICJA rather than POLICJA 'the police'. He reported that his brother had sent him pictures from a vintage vehicles funfair, one of which featured an old militia car from the previous era. While drawing, he remembered it and decided to include that image in his picture. Neither he nor his parents normally used the word.

The situation portrayed in the drawing was clearly connected with the patient's situation at the time of drawing. During the hospitalization, the boy stole numerous items belonging to other patients. He reported that he had been unable to control the impulses to steal. Initially, nobody knew who the culprit was, and the stealing continued. One of the patients reported a theft to the staff, who called in the Police to investigate the situation. After the arrival of the officers, the missing items were found very quickly, and suspicion fell on the boy. The Department's staff reported that the patient had been stressed out by the whole situation. The content of the drawing probably reflects the patient's experiences associated with the arrival of the policemen in the hospital.

Figure 1. Picture drawn by the patient during his stay in hospital

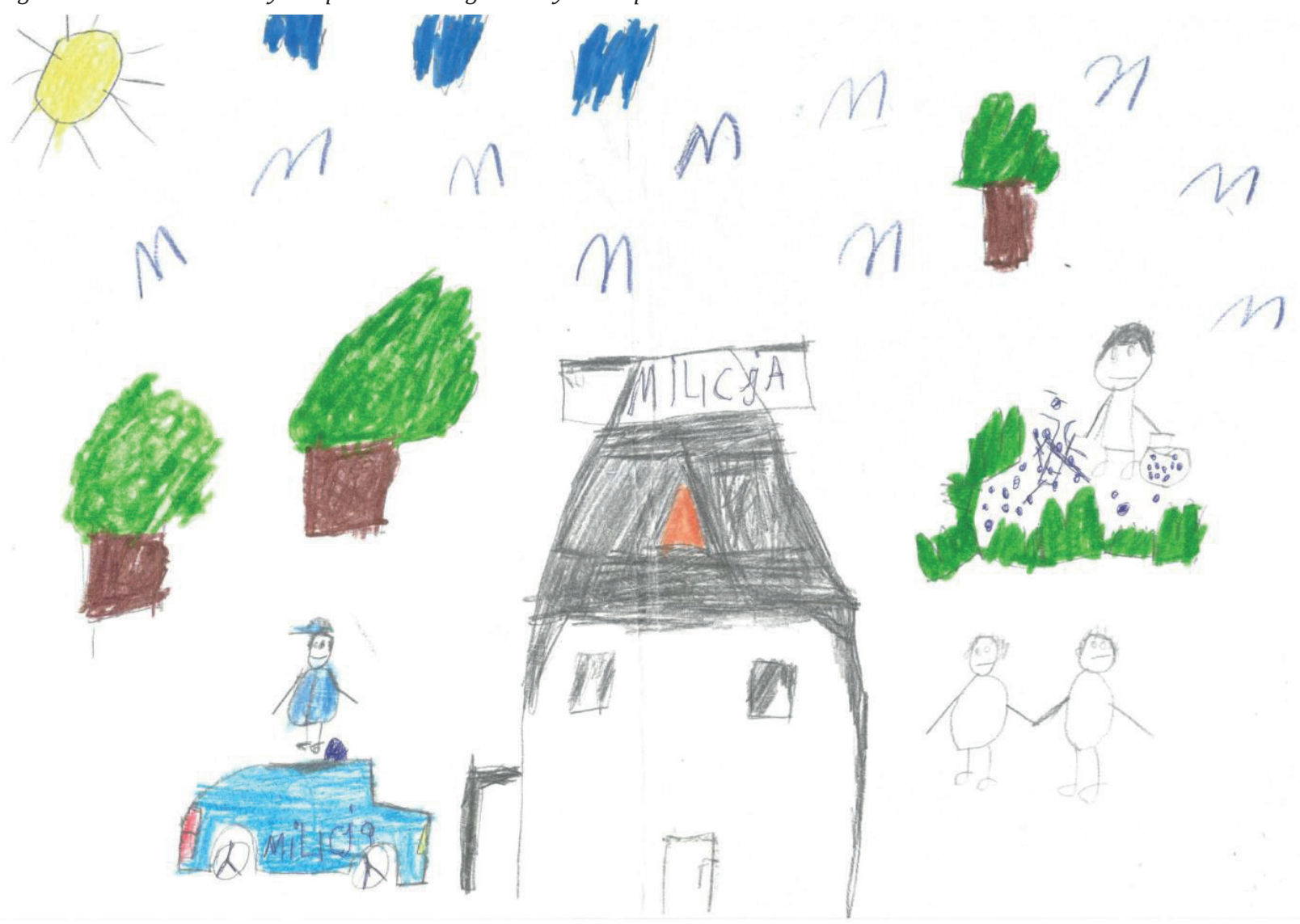

The characters drawn by the patient have a very simple schematic form: they consist of a head, a torso and stick-like arms. This way of drawing is characteristic of the period of ideoplastic art - a sub-period of the schematic stage that occurs in children around the age of five. It should be noted that the patient had been diagnosed with dysgraphia, which may explain why the execution and the general graphomotor skills are below age-level expectations (the patient is 15 years old).

Some of the figures and elements in the drawing have been highlighted by applying more pressure to the pencil and by the use of colours. This applies to the militia building, the policeman and the police car. The patient and his parents have been drawn with a much lighter stroke. These differences are probably due to the fact that the patient had experienced a lot of stress due to the arrival of 
the police officers.

The way the family members are portrayed in the patient's drawing indicates that there are conflicts in the family. The parents are clearly devalued and the eight years older brother has been completely omitted. The patient has placed the figures of his parents holding hands in the bottom right hand corner of the page, outside the centre of the drawing. The fact that the parents are holding hands can be interpreted on the one hand as an expression of their strong bond, and on the other as "demonstrating a unified front" in not accepting their son. The figures of the mother and father are schematic and drawn in just one colour - gray. Perhaps this is an expression of the patient's ambivalent feelings for his parents. On the one hand, he has decided to include them in the picture, because they are important to him, but on the other hand, he has presented them in a way that suggests that he has negative feelings for them: resentment and a feeling of not being accepted and understood.

The analysis of the boy's drawing and his medical history confirm that the patient's relationship with his brother is very weak. On the one hand, the patient admired his brother, a university student, and looked up to him in many ways, on the other, however, he had hard feelings for the brother for not visiting him in the hospital, even though he was studying in the same city, and not even giving him a call. The patient suspected that his brother was ashamed of him.

The patient portrayed himself in a fruit-picking situation. This probably reflects the patient's fantasies about some pleasant past events and wishful thinking: the desire to escape from the painful situation of being hospitalised to a more friendly place. The clinical interview with the patient shows that there are numerous fruit shrubs near his family home, from which he likes to pick fruit.

In conclusion, the analysis of the patient's drawing proved to be very helpful in discovering his current experiences and reflections on his situation. Normal contact with the patient was difficult as he avoided eye contact, spoke laconically, and had lowered insight. Often, it was easier to make inferences about the boy's emotional attitude towards a given person or situation from his gestures (e.g. a brushing away gesture, bowed head) than from his words.

The analysis was based on the patient's drawing, interviews with the patient during his stay in hospital, and interviews with the patient and his parents during a follow-up visit at the Outpatient Clinic.

Course of hospitalization: Upon admission, the patient had good orientation as to place, time and person, was rational and in contact with reality. He showed increased psychomotor drive, a slightly depressed mood, and restlessness. He did not express delusional ideas. He was reluctant to answer questions, especially those related to stealing. During hospitalization, the patient committed numerous petty thefts, which he did not own up to. He usually left the stolen items where they were visible so that the owner could find them. He had not establish relationships with the other patients. On the contrary, he often came into conflict with them. The patient was treated with sertraline at a dose of $50 \mathrm{mg} / \mathrm{dy}$ from day 6 of hospitalization. A therapeutic contract was established. Cognitive-behavioral therapy was provided. The parents were provided with psychoeducation and support. For the larger part of his stay in hospital, the patient did not comply with the therapeutic contract, which required him to report the thefts or impulses to steal to medical staff. A nurse reported that the patient had urinated into a mop bucket and deliberately blocked the toilet. With time, contact with the patient became easier; he was more willing to answer questions. At discharge, the patient was in normal mood and showed an elevated psychomotor activity. He assesses his disposition as good, spoke critically of his previous acts and expressed readiness to continue treatment in an outpatient setting. He was discharged home with instructions to continue sertraline, psychotherapy and sociotherapy, to follow up with a blood test in primary care within 2 months of discharge and to have a follow-up appointment with a mental health provider within a month of discharge. Plans were made for the boy to continue his studies in a sociotherapeutic centre, where he would have received psycho- and sociotherapy, but the parents did not agree to this arrangement. A contract was signed with the parents, stating that they would refrain from using corporal punishment.

\section{Discussion}

\section{Pharmacotherapy of kleptomania:}

There are no clear guidelines for the pharmacotherapy of kleptomania. Kleptomania has been associated with obsessive compulsive disorder, which is why attempts have been made to treat it in a similar way [10]. The effectiveness of SSRIs in the treatment of kleptomania, however, is confirmed by only a few case reports $[11,12,13]$. Even worse, there also exist reports suggesting that SSRIs may induce kleptomania symptoms [14]. Case reports indicate that mood stabilizers (lithium, valproic acid) have a good effect on the course of the disease, but there are no studies with a high credibility rating that would confirm the effectiveness of such therapy $[15,16]$. Naltrexone is the only drug whose effectiveness has been confirmed by experimental studies and not by case reports. A 3-year study showed 
a significant decrease in the urge to steal in 13 out of 17 patients treated with naltrexone. Seven of the patients reported cessation of stealing. The average effective daily dose of naltrexone in the study group was $135.3 \mathrm{mg}$ [17]. In an 8-week double-blind study involving 25 patients, naltrexone was confirmed to be effective in reducing kleptomania symptoms compared to a placebo group. The probable mechanism of action of naltrexone consists in blocking endorphin receptors, and thus reducing the feeling of pleasure after stealing [18].

\section{Psychotherapy of kleptomania:}

Because the medications currently used in the treatment of kleptomania may have side effects and their efficacy is not well confirmed by clinical trials, many authors stress the need to develop effective methods of psychotherapeutic treatment of kleptomania. Cognitivebehavioural psychotherapy (CBT) is regarded to be the most optimal model of intervention for patients with compulsive stealing. The main advantage of cognitivebehavioural models is that diagnosis is made on the basis of an assessment and functional analysis of undesirable behaviours or symptoms of a given patient, what allows the therapist to take a personalized approach. Unfortunately, the literature reports few cases of effective therapy based on the CBT model.

In the cognitive-behavioural model, kleptomania is conceptualized as a set of undesirable behaviours that have developed as a result of instrumental conditioning, low coping skills and various cognitive distortions.

There exist studies which indicate that CBT techniques can be used effectively in the treatment of kleptomania. One such intervention is covert sensitization. The patient is taught to associate images of stealing with the consequences of this act, such as being caught in the act or being arrested. This technique aims to generate anxiety and negative feelings in relation to stealing. Combined with other therapeutic interventions (e.g. teaching of or reinforcing coping strategies) should lead to a reduction in stealing behaviour.

Another strategy that can effectively eliminate the urge to steal is to identify automatic thoughts and dysfunctional beliefs leading to theft, e.g. "I want to prove to myself that I can do it", "I am smarter than others and I won't be caught." According to the assumptions of CBT, a modification of beliefs leads to a modification in behaviour (cessation of undesirable behaviuor).

Currently used CBT methods and techniques are effective in the treatment of kleptomania. Even so, research on the aetiology of the disorder should be continued. This will allow to better understand the functions of the key symptom - impulsive stealing - in the individual patients. Knowing these functions, therapists will be able to suggest to patients what other, more adaptive strategies for functioning and releasing tension they could use in place of stealing [19].

\section{Conclusions}

1. Kleptomania is a disorder that has a very negative impact on the patient's overall development and well-being.

2. Considering the fact that the aetiology of kleptomania has not yet been sufficiently elucidated, doctors should focus on the interview with the patient and his family during treatment. This will allow them to determine the factors that have a likely impact on the occurrence of the unwanted behaviours and to determine their function (e.g. stealing as a way to relieve stress, etc.).

3. In the case reported here, kleptomania developed during methylphenidate treatment.

4. Kleptomania should always be taken into account as a possible cause of stealing during a psychiatric examination, to avoid stigmatization of patients as criminals.

5. Pharmacotherapy and cognitive-behavioural psychotherapy focused on the development of strategies which can help the patient to control the impulse to steal are important components of kleptomania treatment.

\section{Wstęp}

Kleptomania (kompulsywne kradzieże) definiowana jest w ICD 10 i ICD 11 jako powtarzająca się niemożność powstrzymania impulsu kradzieży przedmiotów, które nie służą korzyściom osobistym ani zyskowi materialnemu [1,2]. W ICD 10 sklasyfikowana jest w grupie „nieprawidłowe nawyki i zaburzenia kontroli popędów” (F63.2) obok hazardu, piromanii, trichotillomanii, innych zaburzeń nawyków i impulsów oraz nieokreślonych zaburzeń nawyków i impulsów. W ICD 11 klasyfikowana jest w grupie „zaburzenia kontroli impulsów” obok piromanii, kompulsywnych zaburzeń zachowań seksualnych, zaburzeń eksplozywnych przerywanych oraz innych określonych i nieokreślonych zaburzeń kontroli impulsów. Brakuje danych epidemiologicznych dotyczących rozprzestrzenienia kleptomanii w populacji ogólnej. Szacuje się, że około 5\% osób które dopuściły się kradzieży, może cierpieć z powodu kleptomanii [3].

Istnieją badania, wskazujące na to, iż 7,8\% osób cierpiących z powodu chorób psychicznych wykazuje objawy kleptomanii [4]. Kleptomania w 75\% dotyka 
kobiet, przeważnie młodych, przed 20 r.ż. [5]. Opisywane są 3 postaci tego zaburzenia: 1 - krótkie epizody kradzieży z długimi okresami remisji, 2 - dłuższe okresy kradzieży z krótkimi okresami remisji, 3 - ciągłe epizody kradzieży z niewielką zmiennością częstości. Rozpoznanie kleptomanii opiera się na dwóch kryteriach: wystąpienie 2 lub więcej kradzieży bez uchwytnego zysku dla siebie lub innych osób oraz obecność silnego napięcia przed dokonaniem kradzieży i uczuciem ulgi po jej dokonaniu. W diagnostyce różnicowej należy uwzględnić: zaburzenia depresyjne z kradzieżą (F31-F33), organiczne zaburzenia psychiczne (F00-F09) oraz powtarzające się kradzieże bez zaburzenia psychicznego, gdy są one starannie zaplanowane i istnieje oczywisty motyw osobistego zysku. Nie można także rozpoznać kleptomanii, gdy kradzież odbyła się pod wpływem objawów wytwórczych [1]. DSM-5 zwraca uwagę również na to, iż osoba cierpiąca na kleptomanię zazwyczaj potrafi powstrzymać się od kradzieży przy dużym prawdopodobieństwie natychmiastowego poniesienia konsekwencji [6].

\section{Rys historyczny:}

Kompulsywna kradzież została opisana po raz pierwszy w 1816 roku przez szwajcarskiego lekarza Andrégo Mattheya, przy opisie złodziei, którzy ukradli impulsywnie niepotrzebne przedmioty [7]. Termin kleptomania został pierwszy raz użyty w 1838 roku przez dwóch francuskich psychiatrów (Jean-Étienne Dominique Esquirol i Charles Chrétien Henri Marc) w celu opisania przypadków królów, którzy doznawali niepohamowanej potrzeby kradzieży bezwartościowych przedmiotów. Wspomniani lekarze wiązali tę potrzebę raczej $\mathrm{z}$ zaburzeniem psychicznym niż z brakiem zasad moralnych. W tym okresie przypisywano to zaburzenie głównie kobietom i jako potencjalną przyczynę wskazywano choroby macicy lub zespół napięcia przedmiesiączkowego. $\mathrm{Na}$ początku XX wieku sklasyfikowano kleptomanię jako zaburzenie kontroli impulsów. W 1952 roku została uwzględniona w klasyfikacji DSM-I. Istnienie kleptomanii było w kolejnych latach kwestionowane, czego wyrazem było nieuwzględnienie opisywanej jednostki w DSM-II w 1968 roku. Klasyfikacja DSM-III uwzględniała jednak kleptomanię, podobnie jak w DSM-I, jako zaburzenie kontroli impulsów, obok piromanii, trichotillomanii i zaburzeń eksplozywnych przerywanych oraz patologicznego hazardu [8].

\section{Opis przypadku}

Chłopiec lat 15 został przyjęty do Kliniki Psychiatrii na oddział młodzieżowy w maju 2018 roku. Dotychczas nie był hospitalizowany na oddziałach psychiatrycznych. Od 2011 roku uczęszczał do poradnipsychologicznej z powodu problemów szkolnych - trudności z koncentracją, deficytu uwagi, słabych wyników w nauce oraz zachowań agresywnych. Okresowo przejawiał problemy ze snem związane ze stresem przeżywanym w szkole oraz obgryzał paznokcie. Od 2017 roku pacjent pod opieką psychiatry dziecięcego z powodu ADHD, przyjmując metylofenidat w dawce $20 \mathrm{mg}$ dziennie. Wywiad okołoporodowy i dotyczący chorób somatycznych bez znaczenia. W badaniu EEG zapis prawidłowy, w badaniu MRI niejednoznaczny ubytek zakontrastowania o wymiarach $10 \mathrm{~mm}$ x $5 \mathrm{~mm}$ na granicy zatoki żylnej poprzecznej i esowatej po stronie prawej oraz asymetria zatok poprzecznych. Wywiad rodzinny w kierunku chorób psychicznych ujemny. Pacjent oraz rodzina negowała jakikolwiek kontakt $\mathrm{z}$ substancjami psychoaktywnymi.

\section{Przyczyny hospitalizacji:}

Powodem przyjęcia chłopca do szpitala były powtarzające się epizody kradzieży drobnych przedmiotów ze szkoły i sklepów. Pierwsza kradzież miała miejsce w lutym 2017 roku - pacjent ukradł telefon koledze. Od 6 miesięcy rodzice zauważyli nasilenie problemu. W kwietniu 2018 roku chłopiec ukradł z supermarketu klocki oraz powerbank o łącznej wartości 60 zł. Pytany o motywy swojego postępowania twierdził, iż do kradzieży popycha go niemożliwy do opanowania impuls. Przedmioty, które kradł oddawał lub pozostawiał w takim miejscu, by właściciel mógł je odzyskać. Wyjątkowo zostawiał je do własnego użytku. W związku ze swoim postępowaniem był notowany przez policję.

\section{Sytuacja rodzinna:}

Pacjent mieszka $\mathrm{w}$ domu rodzinnym w średniej wielkości mieście wraz z rodzicami. Ma starszego brata, który mieszka i studiuje na Politechnice w mieście oddalonym o około 100 kilometrów. Znaczna różnica wieku (8 lat) między rodzeństwem wynika z tego, że druga ciąża nie była planowana. Rodzice pacjenta leczyli się z powodu niepłodności. Po narodzinach pierwszego syna byli przekonani, że nie mogą mieć więcej dzieci. Wiadomość o drugiej ciąży była dla nich zaskoczeniem. W chwili poczęcia matka chłopca miała 40 lat, a ojciec 43 lata. Z wywiadu od rodziców pacjenta wynika, że bracia funkcjonują zupełnie odmiennie. Rodzice podkreślają, że starszy syn nie sprawiał nigdy kłopotów wychowawczych. Często porównują synów, wskazując na ogromny dysonans w rozwoju emocjonalnym, intelektualnym pomiędzy braćmi. Rodzice mają problem z akceptacją sposobu i poziomu funkcjonowania młodszego syna. Matka jest krawcową, zaś ojciec pracuje w hucie. Relacje z członkami rodziny pacjent ocenia jako dobre. Z jego relacji wynika, iż w domu zdarzają się kłótnie, podczas których używa się wulgaryzmów. Ojciec chłopca zachowuje się agresywnie po spożyciu alkoholu. Pacjent czasami wdaje 
się $\mathrm{w}$ bójki z bratem, nie potrafi powiedzieć dlaczego dochodzi do takich sytuacji. Rodzice stosowali wobec syna kary cielesne - bicie pasem lub kablem. Chłopiec nie ma jasno określonych obowiązków domowych - pracami domowymi zajmuje się matka.

\section{Sytuacja szkolna:}

Pacjent jest uczniem 3 klasy integracyjnej w gimnazjum. Od początku edukacji obecne były problemy szkolne - deficyt uwagi, zachowania agresywne wobec rówieśników, trudności z koncentracją, dysgrafia. Większość jego ocen stanowiły oceny dopuszczające, nigdy nie powtarzał klasy. Pacjent przyznaje, iż zdarzało mu się popadać w konflikty z rówieśnikami i nauczycielami. W czasie wolnym chłopiec chętnie chodził na spacery z psem, grał w piłkę nożną, na komputerze oraz pracował z tatą w warsztacie przy obróbce drewna.

Pacjent z dużymi trudnościami przeszedł adaptację w gimnazjum. W nowej szkole nie było nikogo ze znajomych ze szkoły podstawowej. Ponadto czuł, że poprzez umieszczenie w klasie integracyjnej podkreślana jest jego odmienność, tj. gorsze funkcjonowanie w sferze intelektualnej.

\section{Badanie psychologiczne:}

W badaniu psychologicznym wykonanym podczas hospitalizacji możliwości intelektualne badanego zostały określone jako poniżej przeciętnej II = $76 \mathrm{w}$ skali pełnej. Wyniki badań wskazują na nieharmonijny rozwój poszczególnych funkcji poznawczych. Porównanie wyników otrzymanych w zakresie skali słownej (II sł =

72) i bezsłownej (II bsł=86) wskazuje na przewage funkcji wykonawczych nad słowno-pojęciowymi u pacjenta. Biorąc pod uwagę zróżnicowane wyniki pacjenta - rozpiętość wyników przeliczonych w poszczególnych podtestach na poziomie 10 punktów, należy z dużą ostrożnością interpretować ilorazy inteligencji uzyskane w skalach słownej i bezsłownej. W analizowanym przypadku bardziej trafne wydaje się zastosowanie analizy trójczynnikowej do opisu funkcjonowania intelektualnego pacjenta. Model trójczynnikowy obejmuje następujące czynniki: Rozumowanie Słowne (RS), Organizację Percepcyjną (OP) oraz Pamięć i Odporność na Dystraktory (POD). Czynnik RS mierzy rozumienie i wiedzę werbalną, zdobyte dzięki nauce szkolnej jak i spontanicznej. Pokazuje czy badany jest w stanie wykorzystać zdolności werbalne w nowych sytuacjach. Czynnik OP odzwierciedla zdolności interpretowania i przetwarzania materiału wzrokowego $\mathrm{z}$ uwzględnieniem ograniczenia czasowego. Natomiast ostatni czynnik POD jest uznawany za dobrą miarę uwagi i koncentracji, obejmuje podtesty angażujące pamięć krótkotrwałą i operowanie liczbami.

Analiza wyników podtestów skali WISC-R wchodzących w skład poszczególnych czynników pokazuje, że pacjent jedynie w zakresie czynnika Organizacji Percepcyjnej otrzymał wynik na poziomie przeciętnym. Wyniki uzyskane w zakresie czynników Rozumowanie Słowne oraz Pamięć i Odporność na Dystraktory wskazują, że funkcje intelektualne mierzone przez wyżej wymienione czynniki są rozwinięte u pacjenta na niskim poziomie. W literaturze podkreśla się, że badani ze zdiagnozowanym zespołem hiperkinetycznym uzyskują niskie wyniki w zakresie czynnika POD [9]. Zależność ta znalazła potwierdzenie także w przypadku omawianego pacjenta. Również niski wynik w zakresie czynnika RS znajduje odzwierciedlenie w niskich wynikach w nauce pacjenta i znaczących brakach w wiedzy formalnej i o świecie. Można przypuszczać, że pierwotną przyczyną trudności w nauce u pacjenta były deficyty w zakresie uwagi i koncentracji, które przyczyniły się do licznych niepowodzeń szkolnych. Te z kolei doprowadziły do spadku motywacji do nauki, niechęci do wysiłku intelektualnego, a w efekcie pogłębiły istniejące deficyty wiedzy szkolnej. Biorąc pod uwagę aktualny problem pacjenta - kleptomanię, aktualna ocena jego zdolności intelektualnych rokuje negatywnie w zakresie powodzenia psychoterapii poznawczo-behawioralnej. W omawianym przypadku bardziej uzasadnione będzie wdrażanie interwencji stricte behawioralnych względem technik poznawczych.

\section{Opis rysunku pacjenta:}

(ryc. 1) Rysunek powstał spontanicznie, w czasie wolnym. Pacjent relacjonuje, że narysował go „z nudów, bo był weekend, nie było lekcji, ani żadnych zajęć”.

Na rysunku znalazł się, w jego centralnej części, budynek z napisem „MILICJA”. Z lewej strony pacjent narysował policjanta i samochód, który także podpisał "MILICJA". Po prawej stronie rysunku widnieją trzy postacie, dwie trzymają się za ręce. Trzecia trzyma koszyk i zbiera owoce. Na rysunku znalazły się również chmury, słońce, trzy drzewa i lecące ptaki. Pacjent wytłumaczył użycie wyrazu MILICJA zamiast POLICJA. Relacjonował, że brat przysłał mu zdjęcia ze zlotu zabytkowych pojazdów i tam widział wóz milicyjny z poprzedniej epoki. Podczas rysowania przypomniał sobie o tym i to uwzględnił. Zazwyczaj ani on, ani jego rodzice nie używają tego słowa. Sytuacja przedstawiona na rysunku ma ewidentny związek z bieżącą sytuacją pacjenta w chwili powstawania rysunku. Pacjent, w okresie hospitalizacji, dopuszczał się licznych kradzieży przedmiotów należących do pozostałych pacjentów. Relacjonował, że nie był w stanie kontrolować impulsów prowadzących do kradzieży. Początkowo nie było wiadomo kto był sprawcą, 
Figure 1. Picture drawn by the patient during his stay in hospital

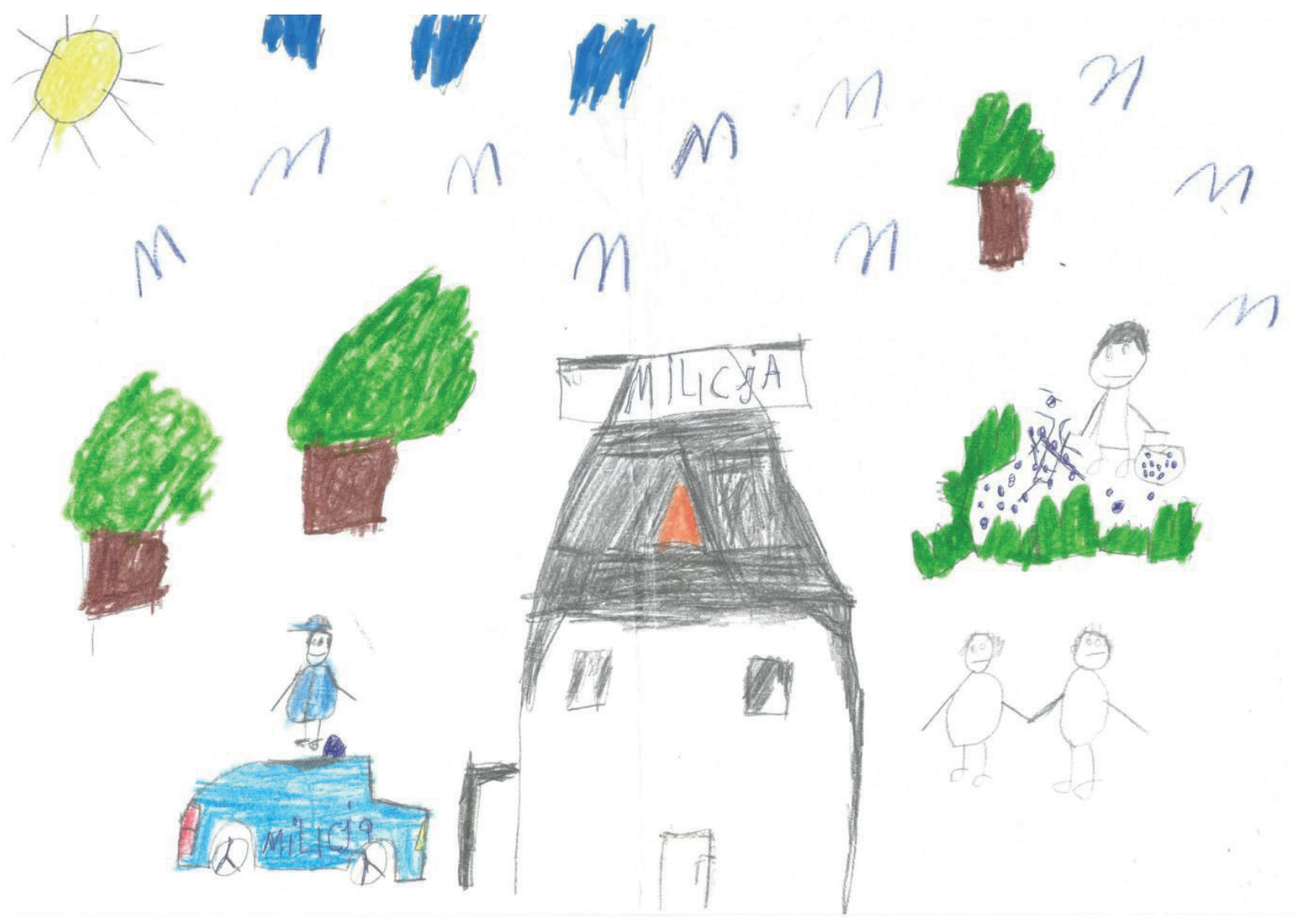

a nadal ginęły nowe przedmioty. Jeden $\mathrm{z}$ pacjentów zgłosił kradzież personelowi, który wezwał Policję celem wyjaśnienia zaistniałej sytuacji. Po przybyciu funkcjonariuszy zaginione przedmioty bardzo szybko się znalazły, podejrzenie kradzieży padło na pacjenta. Z relacji personelu Oddziału wynika, że pacjent bardzo się zestresował całą sytuacją. Prawdopodobnie treść rysunku odzwierciedla przeżycia pacjenta związane z przybyciem Policji do szpitala.

Postacie rysowane przez pacjenta są znacznie uproszczone, zgeometryzowane, składają się z głowy, tułowia i rąk w postaci kresek. Ten sposób rysowania jest charakterystyczny dla okresu ideoplastyki - podokresu schematu prostego i występuje u dzieci około 5 r.ż. Należy zaznaczyć, że u pacjenta zdiagnozowano dysgrafię, co może tłumaczyć obniżenie poziomu wykonania rysunku i ogólnych umiejętności grafomotorycznych (wiek pacjenta - 15 lat).

Część postaci i elementów rysunku została wyróżniona poprzez silniejszy nacisk kredki i użycie kolorów. Dotyczy to budynku Milicji, policjanta i radiowozu. Pacjent i jego rodzice zostali przedstawieni za pomocą kreski o znacznie mniejszym nacisku. Prawdopodobnie różnice te wynikają z faktu przeżywania przez pacjenta dużego stresu w związku z przybyciem
Policji.

Przedstawienie członków rodziny na rysunku pacjenta wskazuje na występowanie pewnych konfliktów rodzinnych. Rodzice są wyraźnie dewaloryzowani, natomiast o 8 lat starszy brat został zupełnie pominięty. Pacjent umieścił wizerunek trzymających się za ręce rodziców w prawym dolnym rogu kartki, czyli poza centralną częścią rysunku. Trzymanie się za ręce rodziców można interpretować z jednej strony jako wyraz ich silnej więzi, a z drugiej jako „trzymanie wspólnego frontu” w braku akceptacji dla osoby pacjenta. Postać matki i ojca jest znacznie uproszczona, narysowana jednym - szarym kolorem. Być może jest to wyraz ambiwalentnych uczuć pacjenta do rodziców. Z jednej strony zdecydował się umieścić ich na rysunku, jako osoby ważne dla niego, jednak przedstawił ich w sposób, który sugeruje, że ma do nich negatywne uczucia w postaci żalu, czuje się nierozumiany i nieakceptowany.

Analiza rysunku i dane z wywiadu potwierdzają, że więź pacjenta z bratem jest znacznie osłabiona. Z jednej strony pacjent podziwia brata - studenta, imponuje mu na wielu polach, z drugiej ma do niego żal, że nie odwiedzał go w szpitalu, nie dzwonił, choć studiuje w tym samym mieście. Pacjent podejrzewa, że brat się go wstydzi.

Pacjent przedstawił samego siebie w sytuacji 
zbierania owoców. Prawdopodobnie jest to wynikiem fantazji pacjenta na temat przyjemnych zdarzeń $\mathrm{z}$ przeszłości i życzeniowego myślenia, aby uciec z obciążającej sytuacji hospitalizacji w bardziej przyjazne miejsce. Z wywiadu wynika, że obok domu pacjenta znajdują się liczne krzewy owocowe, z których pacjent chętnie zbiera owoce.

Podsumowując, należy zaznaczyć, że analiza rysunku w przypadku pacjenta okazała się bardzo pomocna w odkryciu jego aktualnych przeżyć i przemyśleń na temat jego sytuacji. Tradycyjny kontakt z pacjentem był utrudniony poprzez unikanie kontaktu wzrokowego, lakoniczne wypowiedzi i obniżony wgląd. Często o nastawieniu emocjonalnym pacjenta do danej osoby lub sytuacji łatwiej można było wnioskować z jego gestykulacji (np. machnięcie ręką, opuszczenie głowy) niż na podstawie wypowiedzi.

Analiza przeprowadzona na podstawie: rysunku pacjenta, rozmów z pacjentem w okresie hospitalizacji, rozmowy $\mathrm{z}$ pacjentem $\mathrm{i}$ jego rodzicami podczas wizyty kontrolnej po opuszczeniu szpitala w Poradni Przyklinicznej.

\section{Przebieg hospitalizacji:}

Pacjent podczas przyjęcia zorientowany prawidłowo auto- i allopsychicznie, w logicznym kontakcie. Napęd psychoruchowy podwyższony, nastrój nieco obniżony, obecny niepokój ruchowy. Treści urojeniowych nie wypowiadał. Niechętnie odpowiadał na pytania, szczególnie te, związane z kradzieżami. Podczas hospitalizacji pacjent dopuszczał się licznych drobnych kradzieży, do których się nie przyznawał. Zabrane przedmioty zazwyczaj odkładał $\mathrm{w}$ widoczne miejsca, tak aby właściciel mógł je znaleźć. Nie nawiązał relacji z innymi chorymi, popadał z nimi w konflikty. Leczony za pomocą sertraliny w dawce $50 \mathrm{mg}$ od 6 . dnia hospitalizacji. Zawarto kontrakt terapeutyczny, prowadzono terapię kognitywno-behawioralną, psychoedukację i wsparcie dla rodziców. Pacjent przez większość pobytu nie przestrzegał kontraktu terapeutycznego, zakładającego zgłaszanie faktu kradzieży lub impulsów do kradzieży członkom personelu medycznego. Z relacji pielęgniarki wiadomo, iż pacjent oddał mocz do wiadra z mopem, a także umyślnie zatkał toaletę. Z czasem kontakt z pacjentem stawał się łatwiejszy, chętniej odpowiadał on na pytania. W dniu wypisu był w nastroju wyrównanym, podwyższonym napędzie psychoruchowym. Pacjent określał swoje samopoczucie jako dobre, wyrażał krytycyzm wobec swoich czynów oraz chęć kontynuowania leczenia w warunkach ambulatoryjnych. Wypisany z zaleceniami dalszego zażywania sertraliny, kontynuowania psychoterapii i socjoterapii, kontrolnego badania

parametrów krwi w ramach $\mathrm{POZ}$ w przeciągu
2 miesięcy od wypisu, kontroli w poradni zdrowia psychicznego $\mathrm{w}$ przeciągu miesiąca od wypisu. Zaplanowano dalszą edukację szkolną wraz z psycho- i socjoterapią w ośrodku socjoterapeutycznym, jednak rodzice nie wyrazili na to zgody. Z rodzicami podpisano kontrakt zakładający zaniechanie kar cielesnych wobec syna.

\section{Dyskusja}

\section{Farmakoterapia kleptomanii:}

Nie ma jasnych wytycznych w kwestii farmakoterapii kleptomanii. Kleptomania była kojarzona z zaburzeniami obsesyjno-kompulsywnymi, dlatego podejmuje się próby leczenia jej w podobny sposób [10]. Skuteczność SSRI w leczeniu kleptomani potwierdzają pojedyncze opisy przypadków [11,12,13]. Istnieją jednak opisy sugerujące, iż SSRI mogą indukować objawy kleptomanii [14]. Opisy przypadków wskazują na pozytywny wpływ stabilizatorów nastroju (lit, kwas walproinowy) na przebieg choroby, brakuje jednak badań o dużej wiarygodności potwierdzających skuteczność takiej terapii $[15,16]$. Jedynym lekiem którego skuteczność potwierdzono badaniami, a nie opisami przypadków, jest naltrekson. 3-letnie badanie przeprowadzone na 17 pacjentach wykazało znaczący spadek potrzeby dokonywania kradzieży u 13 badanych. 7 pacjentów potwierdziło całkowite zaprzestanie dokonywania kradzieży. Przeciętna efektywna dawka dobowa naltreksonu w grupie badanej wynosiła 135,3 mg [17]. W 8-tygodniowym badaniu z zastosowaniem podwójnie ślepej próby, w którym udział wzięło 25 pacjentów, potwierdzono skuteczność naltreksonu w redukowaniu objawów kleptomani w porównaniu do grupy przyjmującej placebo. Prawdopodobnym mechanizmem działania naltreksonu jest blokowanie receptorów endorfin, a tym samym ograniczenie odczuwania przyjemności po dokonaniu kradzieży [18].

\section{Psychoterapia kleptomanii:}

W literaturze często wskazuje się na potrzebę rozwijania skutecznych metod psychoterapii kleptomanii, ze względu na możliwe skutki uboczne obecnie stosowanej farmakoterapii i jednocześnie słabo potwierdzoną w badaniach klinicznych skuteczność. Jako najbardziej optymalny model oddziaływań wskazuje się psychoterapię poznawczo-behawioralną. Główną zaletą modeli poznawczo-behawioralnych jest formułowanie diagnozy $\mathrm{w}$ oparciu o ocenę i analizę funkcjonalną niepożądanych zachowań czy objawów danego pacjenta, co pozwala na zindywidualizowane podejście. Jakkolwiek w literaturze opisano niewiele przypadków efektywnej terapii w oparciu o model CBT. 
Kleptomania, w modelu poznawczo-behawioralnym, jest konceptualizowana jako zbiór niepożądanych zachowań, które ukształtowały się w wyniku warunkowania instrumentalnego, niskich umiejętności radzenia sobie w sytuacjach trudnych oraz jako konsekwencja różnorodnych zniekształceń poznawczych. Istnieją badania wskazujące na skuteczność technik CBT $\mathrm{w}$ leczeniu kleptomanii. Jedną z tego typu interwencji jest tzw. ukryta sensytyzacja. Zastosowanie tej techniki polega na uczeniu pacjenta łączenia wyobrażeń kradzieży z konsekwencjami własnych czynów w postaci złapania na gorącym uczynku czy osadzenia w areszcie. Wspomniana technika ma na celu systematyczne generowanie niepokoju i negatywnych uczuć związanych z kradzieżami, co w połączeniu z innymi interwencjami terapeutycznymi (np. uczeniem lub wzmacnianiem strategii radzenia sobie), powinno prowadzić do zmniejszenie nasilenia kradzieży.

Kolejną, skuteczną strategią w eliminowaniu impulsywnych kradzieży jest identyfikowanie automatycznych myśli i dysfunkcjonalnych przekonań prowadzących do kradzieży np. „Chcę udowodnić sobie, że mogę to zrobić.", „Jestem mądrzejszy od innych i nie zostanę złapany." Zgodnie z założeniami terapii CBT modyfikacja przekonań prowadzi do modyfikacji zachowania polegającej na zaprzestaniu niepożądanych zachowań.

Obecnie stosowane metody i techniki CBT są skuteczne $\mathrm{w}$ terapii kleptomanii, aczkolwiek wskazane jest kontynuowanie badań nad etiologią omawianego zaburzenia. Pozwoli to lepiej poznać funkcje kluczowego objawu - impulsywnych kradzieży, w przypadku poszczególnych pacjentów. Umożliwi to proponowanie pacjentom innych, bardziej przystosowawczych strategii funkcjonowania i rozładowywania napięć, w miejsce wyeliminowanych kradzieży [19].

\section{Wnioski}

1. Kleptomania jest zaburzeniem silnie oddziałującym na życie chorego.

2. Mając na uwadze fakt, że etiologia kleptomanii nie została dotychczas wyjaśniona w dostateczny sposób, podczas leczenia ważna jest koncentracja na wywiadzie $\mathrm{z}$ pacjentem i jego otoczeniem. Pozwoli to na określenie czynników mających prawdopodobny wpływ na wystąpienie niepożądanych zachowań oraz na określenie ich funkcji (np. kradzież jako sposób na rozładowanie napięcia itp.).

3. Kleptomania w opisanym przypadku rozwinęła się $\mathrm{w}$ trakcie przyjmowania metylofenidatu.

4. Zawsze należy brać pod uwagę kleptomanię $\mathrm{w}$ trakcie badania psychiatrycznego osoby dopuszczającej się kradzieży, aby nie stygmatyzować osoby chorej klasyfikując ją jako przestępcę.

5. Istotnymi elementami leczenia kleptomanii jest farmakoterapia i psychoterapia kognitywno -behawioralna ukierunkowanej na rozwój strategii pozwalających na opanowanie impulsów popychających do kradzieży.

\section{Conflict of interest}

The authors have declared no conflict of interest.

\section{References:}

1. World Health Organization (WHO). The ICD -10 Classification of Mental and Behavioural Disorders: Clinical Descriptions and Diagnostic Guidelines. Geneva 1992: World Health Organization.

2. ICD 11. [online]: https://icd.who.int/browse11/l-m/en\#/http:// id.who.int/icd/entity/804604349

3. Sipowicz J, Kujawski R: Kleptomania czy kradzież pospolita - trudności diagnostyczno-orzecznicze. Psychiatr. Pol. 2018;52(1): 81-92.

4. Grant JE, Levine L, Kim D, Potenza MN: Impulse control disorders in adult psychiatric inpatients. Am J Psychiatry. 2005;162: 2184-2188.

5. Hässler F: Aufgehbene Schuldfähigkeit im Falle einer Kleptomanie. XII Polsko-niemiecka konferencja naukowoszkoleniowa z psychiatrii sądowej. Kraków, 4-5.09.2015.

6. American Psychiatric Association. Diagnostic And Statistical Manual of Mental Disorder. 5th edition (DSM-5). American Psychiatric Association, Washington 2013.

7. Grant JE, Odlaug BL: Kleptomania: Clinical characteristics and treatment. Rev. Bras. Psiquiatr. 2008; 30 (Suppl. 1): 11-15.

8. Guerdjikova AI, McElroy SL: Kleptomania. The Encyclopedia of Clinical Psychology. 23.01.2005.

9. Krasowicz-Kupis G, Wiejak K: Skala inteligencji Wechslera dla dzieci (WISC-R) w praktyce psychologicznej. Warszawa. 2008 Wydawnictwo naukowe PWN.

10. Grant JE: Understanding and Treating Kleptomania: New Models and New Treatments. Isr J Psychiatry Relat Sci 2006 Vol 43 No. 2 81-87.

11. Lepkifker E, Dannon PN, Ziv R, Iancu I, Horesh N, Kotler M: The treatment of kleptomania with serotonin reuptake inhibitors. Clin Neuropharmacol. 1999 Jan-Feb; 22(1): 40-3.

12. Kraus JE: Treatment of kleptomania with paroxetine. J Clin Psychiatry. 1999 Nov; 60(11): 793.

13. Chong SA, Low BL: Treatment of kleptomania with fluvoxamine. Acta Psychiatr. Scand. 1996; 93. 314-315.

14. Kindler S, Dannon P, Iancu I, Horesh N, Kotler M: Emergence of kleptomania during treatment for depression with serotonin selective reuptake inhibitors. Clin. Neuropharmacol. 1997 Apr; 20(2): 126-9.

15. McElroy SL, Pope HG, Hudson JI, Keck PE, Jr., White KL.: Kleptomania: A report of 20 cases. Am J Psychiatry 1991; 148: 652-657.

16. Grant JE, Odlaug BL: Kleptomania: Clinical characteristics and treatment. Rev. Bras. Psiquiatr. 2008; 30 (Suppl. 1): 11-15.

17. Grant JE: Outcome Study of Kleptomania Patients Treated With Naltrexone: A Chart Review. Clinical Neuropharmacology. 2005; 28(1):11-14.

18. Grant JE, Kim SW, Odlaug BL: A double-blind, placebo-controlled study of the opiate antagonist, naltrexone, in the treatment of kleptomania. Biol Psychiatry. 2009; 65(7): 600-606. 
19. Kohn CS: Conceptualization and treatment of kleptomania behaviors using cognitive and behavioral strategies. Int. J. Behav. Consult. Ther. 2006; 2(4): 553-559. 17. Grant JE: Outcome Study of Kleptomania Patients Treated With Naltrexone: A Chart Review. Clinical Neuropharmacology. 2005; 28(1):11-14.

\section{Corresponding author}

Olga Padała

I Department of Psychiatry, Psychotherapy and Early Intervention, Medical University of Lublin, Poland email: olga.padala@gmail.com

Otrzymano: 22.08.2019

Zrecenzowano: 22.08.2019

Przyjęto do druku: 26.08.2019 